In recent years, Keller interested himself in the study of evolution, particularly in ecological work bearing on evolution. It appears from his recent papers that he considered that environmental characters exerted some effect upon inherited modifications, though he did not under-rate the importance of natural selection, and he remained an ardent adherent of Darwinism.

Keller took part in international congresses of botany and soil science, and he published articles not only in Russian but also in several foreign periodicals. At the time of his death he was widely known and esteemed by botanists all over the world. N. A. Maximov.

(Translated by E. Ashby.)

I sHouLD like to add to Maximov's note a personal tribute to B. A. Keller. I called on him in his flat in Moscow early in 1945, and he gave me a friendly and generous welcome. He was a sick man, but he was enthusiastically working at a book on ecology and evolution. He was very anxious that I should become familiar with the flora around Moscow, and to that end he gave me his own copy of the handbook to the local flora, and instructions as to the places I should visit. We met several times during the year, and Keller was always willing to help me. I attended his funeral ceremony in the biological block of the Academy of Sciences; and it was clear from the speeches made there by his students and by a representative of workers from the botanic gardens, that Keller had great influence upon the younger generation of botanists, and that his name is not only honoured but also held in deep affection by those who knew him.

E. Ashry.

\section{Dr. J. M. Derscheid}

THE death has recently been confirmed of Dr. Jean-Marie Eugène Derscheid, professor of biology of the Colonial University of Antwerp, who was shot at the prison of Brandebourg on March 13, 1944, after thirty months imprisonment in Germany.

Derscheid was born at Sterrebeek on May 19, 1901, and from earliest youth showed a great propensity for natural sciences and art. At the age of seventeen he interrupted his studies to endeavour to join in the fighting by attempting to pass through Holland and reach the front behind the Yser, but was taken prisoner and was not liberated until the Armistice in 1918. In 1919 he began studying medicine, but later changed to take a degree in natural sciences.

In 1924 Derscheid was awarded the gold medal of the Concours Interuniversitaire for the period 1922-24 for his theses on the classification of birds and the olfactory organs of fish. During 1924-26 he acted as temporary keeper of the Colonial Museum at Tervueren, and in 1926 was appointed by the King of the Belgians to accompany the American expedition led by Carl Akeley to explore the volcanic region of Kivu. On the death of Carl Akeley, Derscheid took charge of the expedition, and the information he obtained contributed greatly to the creation of the Albert National Park, the first national park of the Congo. In addition, he was chief of the International Office for the Protection of Nature in Brussels.

Derscheid specialized in the fauna of the Belgian Congo, among the most important of his papers being "Recherches anatomiques sur l'Okapi. 1, Le caecum ot la glande ileocaecale. 2, La rate" (Revue de Zoologie et Botanique Africaine).
$\mathrm{He}$ was also a singularly successful aviculturist and his collection of birds at Sterrebeek was justly world-famed. He was also no mean artist, and many of his ornithological articles were illustrated by his own drawings.

Derscheid was a fellow of the Zoological Society of London and of the Audubon Society of America, an honorary life-member of the Wild Life Preserva. tion Society of Australia and was awarded the medal of the Société d'Acclimatation de France.

In 1940 Derscheid rejoined his regiment, and having fought into France was demobilized and returned to Belgium in the autumn of 1940. His perfect knowledge of English made him an invaluable aid to escaping British airmen, and in addition he gave considerable service in sending secret information to the Allies, with the result that he was arrested by the Gestapo in October 1941.

The tragic end of Derscheid's career will be both a loss to science and a grief to his colleagues, who will long remember his peculiar charm of manner and vital personality.

Phyllis Barclay-SMith.

$$
\text { Mr. A. J. W. Selley }
$$

Alfred John William Selley died at Arundel, Sussex, on November 28 at the age of ninety-one. Born in Devon, Mr. Selley went to Bristol as a young man in 1874 and lived there until the war period.

Selley was a brilliant and ardent collector, and many exhibits in the City Museum, Bristol, are a silent witness to his devoted services over so many years. At first he concentrated on the surface flint implements of the Mendip area. He was intimately acquainted with the district and often would spend a whole day traversing and re-traversing a ploughed field so that every portion of it was inspected. Later in life he also took an interest in bygones of all ages, and due entirely to his passion for collecting, many an interesting object has been preserved. Science and history owe much to those who devote their leisure hours to the acquiring of facts and material. Selley was one of this small but energetic group.

Selley was a member of the Bristol Naturalists' Society for many years and was made an honorary momber in 1939 in view of his distinguished services to the cause of local prehistoric studies. $\mathrm{H}_{\theta}$ was retiring and modest; he was essentially an individualist and loved to be alone in the open field for long hours searching for any object that awaited his keen observational powers.

F. S. WALIIS.

WE regret to announce the following deaths:

Prof. A. M. Adamson, professor of entomology in the Imperial College of Tropical Agriculture, Trinidad, on December 24, 1945, aged forty-four.

Dr. P. Amaury-Talbot, an authority on Nigeria, on December 28, 1945, aged sixty-eight.

Dr. Thomas Barbour, director of the Museum of Comparative Zoology and professor of zoology, Harvard University, who was a foreign member of the Zoological Society of London, on January 8, aged sixty.

Dr. Leo Cernosvitov, a specialist on Oligochaete worms, on December 15, 1945, at Ascot.

Mr. R. C. Shannon, entomologist of the International Health Division, Rockefeller Foundation, and an eminent American authority on mosquitoes, in Trinidad, on March 6, 1945. 